Masayuki SHINOHARA: Variation in the Number of Nucleoli in Rice Species Having the AA Genome. Jap. Jour. Genet. Vol. 37 No. 3 (1962): 243-247.

\title{
稲属 $\mathrm{AA}$ ゲノム群の仁数変異について \\ 篠 $\underset{\substack{\text { 婂 } \\ \text { 国立遺伝学研究所 }}}{\text { 行 }^{11}}$
}

Received July 29, 1961

\section{Résumé}

The number of nucleoli newly formed in telophasic cells of root tips was counted in rice species having the AA genome, namely, Oryza sativa, O. perennis, O. sativa f. spontanea, $O$. glaberrima and $O$. breviligulata, taking for each species about twenty strains from the stocks kept in the National Institute of Genetics, Japan. The root tips of germinating seeds were fixed in Lewitsky's solution $\left(5 \% \mathrm{CrO}_{3} 3\right.$ : Formalin 1), and after hydrolysis in warm $\mathrm{N}-\mathrm{HCl}$ for about 20 minutes squashed with $1 \%$ aceto-carmine. The results obtained from the respective strains are given in Tables $1 \sim 4$, and the distribution of the mean nucleolar number in each species is shown in Table 5. As shown in those tables, the variation in nucleolar number is continuous. If strains with more than 2.1 nucleoli per cell are considered to represent the quadri-nucleolar, and those with less than 2.1 the bi-nucleolar type, all the species investigated can be said to have both types. However, it is found that strains belonging to $O$. perennis and $O$. sativa f. spontanea, as well as those of the Indica type of $O$. sativa, are mostly of quadri-nucleolar type, while strains of $O$. breviligulata and O. glaberrima are of bi-nucleolar type. Another point of interest was that plants collected from adjacent sites, belonging actually to the same population, showed a marked difference. This indicates that the chromosomes of plants within the same population may differ in nucleolus-forming ability.

(This work was supported by Grant RF57080 from The Rockefeller Foundation.)

National Institute of Genetics, Misima

従来, 栽培稲 Oryza sativa は品種により化数が異なることが知られている。インド品種と日本品種との 差異は最初 Selim (1930) によって指摘された。酒井 (1938) はインド型と日本型との間で異なるとし, 前 者を四型, 後者を双仁型と呼んだ。しかし，Oka and Kao (1956) は変異が連続的であると報告してい る。このような品種によると数の差異は栽培稲品種の系統発生的分化に関連する一つの形質であると思われ る。したがって野生稲から栽培稻がどの上うにして発生したかという問題を研究する一つの手がかりとして, 野生稲に怙ける化数の変異を調べることは興味のある問題である。しかし, 今まで野生稻についてはそのよ うな報告がない。筆者は栽培稲, O. sativa の先祖型と考宇られる野生榉, O. perennis 並びに O. sativa

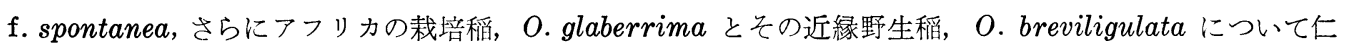
数の変異を観察した。

\section{材料および方法}

国立遺伝学研究所に保存されているイネ属系統のうち, O. sativa L., O. sativa f. spontenea Roschev., O. perennis Moench., O. glaberrima Steud., O. breviligulata A. Chev. et Roehr. 海属するるの (AA ゲノムをるつ) 合計 91 系統（それぞれ約 20 系統）を用いた。アジア産の O. perennis と O. sativa f. spontanea との間には中間型が連続変異を示し分類が困難であることが知られているから，この群に属す る系統は Morishima, Oka and Chang (1961) の判別式により, Perennis 型と Spontanea 型に分類した。 ペトリ皿に沪紙を敷き水を含ませた上に種子を置床し, 主根が約 $1 \mathrm{~cm}$ の長さに伸びた頃, 根端をレヴィッ

1) 日本大学農獣医学部 


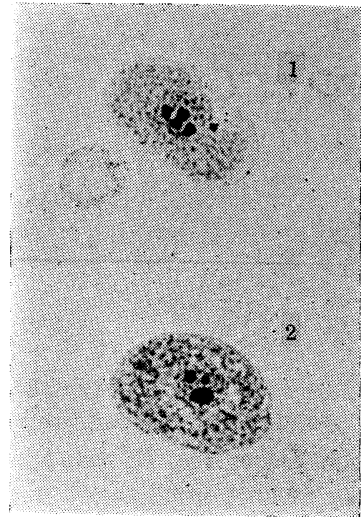

Fig. 1. Nucleoli formed in telophasic root-tip cells:

(1) O. sativa, Japonica type (647)

(2) O.perennis, Barthii type (Af 67)
キー液 (5\% $\mathrm{CrO}_{3} 3:$ Formalin 1) で 3 時間または それ以上固定 した。固定後, 温水で洗い, $60^{\circ} \mathrm{C} の \mathrm{~N}-\mathrm{HCl}$ で約 20 分間加水分解 を特こなった。染色には $1 \%$ 醋酸カーミンを用い, 拈しつぶし法に よってプレパラートを作成した。各系統 100 個の終期細胞を 2,000 倍で観察し，新しく形成された代数を記録した。休止期に入ると 仁は融合して 1 個となることが多いので，休止期に近ずいた細胞を 観察に含めないよう注意した。

\section{観察結果および考察}

観察の結果は Tables 1 4 の如くであった。Table 5 は各種に 特壮る偻の変異の幅をみるため, Tables 1 4k示す平均仁数の分 布を一括したものである。これらの表に示すデータから数の変異 は連続的であることが認められる。いま，かりに平均細胞当り仁数 2.1 以上の系統を 4 亿型，それ以下のものを 2 亿型とすると，AAゲノムを有する種にはどれにる 2 亿型と 4 亿型が含まれることにな る。しかし,その頻度を比較すると, Perennis 型特よび Spontanea 型の野生稲には 4 亿型が多く, アフリカの O. glaberrima 特よび O. breviligulata の系統は大部分 2 亿型である。

観察系統印の 4 亿型（平均值 2.1 以上）の頻度をみると，O. sativa では $45 \%$ ，O. perennis と 0 .

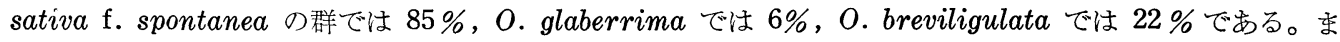
た，O. sativa では従来知られているょうに，インド型 (Continental type) は日本型 (Insular type) より 4 型の頻度が高いことが見出され，その頻度 $73 \%$ は perennis などの野生稲の $85 \%$ に近ずいている。一 般的には，野生種には栽培種より 4 亿型が多く, sativa そその類縁野生種には glaberrima とその類縁野

Table 1. Variation in nucleolar number among strains of $O$. sativa

\begin{tabular}{|c|c|c|c|c|c|c|c|}
\hline \multirow{2}{*}{$\begin{array}{l}\text { Strain } \\
\text { No. }\end{array}$} & \multirow{2}{*}{ Type } & \multirow{2}{*}{ Origin } & \multirow{2}{*}{ Local name } & \multicolumn{3}{|c|}{$\begin{array}{l}\text { No. of cells showing } \\
\text { each nucleolar number }\end{array}$} & \multirow{2}{*}{$\begin{array}{l}\text { Mean No. } \\
\text { per cell }\end{array}$} \\
\hline & & & & 2 & 3 & 4 & \\
\hline 101 & Indica & Taiwan & Ukuh-tsing-you & 71 & 24 & 5 & 2.3 \\
\hline 104 & " & $" 1$ & Fen-tu & 88 & 3 & 9 & 2.2 \\
\hline 108 & " & " & Pei-ku & 99 & 0 & 1 & 2.02 \\
\hline 124 & $"$ & " & Shuang-chiang & 68 & 26 & 6 & 2.4 \\
\hline 414 & " & India & P. T. B. 10 & 68 & 29 & 3 & 2.4 \\
\hline 417 & " & " & A. D. T. 14 & 94 & 6 & 0 & 2.1 \\
\hline 439 & " & " & Gurdei mymensingh & 94 & 4 & 2 & 2.1 \\
\hline 444 & " & " & Padi type 52 & 100 & 0 & 0 & 2.0 \\
\hline 451 & " & " & Surjamukhi & 94 & 6 & 0 & 2.1 \\
\hline 721 & " & China & Hsiang-san-shasan & 100 & 0 & 0 & 2.0 \\
\hline 724 & " & " & Kun-ming-tsiehkuan & 87 & 10 & 3 & 2.2 \\
\hline 642 & Japonica & Celebes & Padi kasalle & 98 & 2 & 0 & 2.02 \\
\hline 647 & $"$ & " & Padi ase banda & 85 & 15 & 0 & 2.2 \\
\hline 657 & " & " & Padi ladangase & 99 & 1 & 0 & 2.01 \\
\hline 504 & " & Taiwan & Taichung no. 65 & 98 & 2 & 0 & 2.02 \\
\hline 521 & " & Japan & Kisshin & 100 & 0 & 0 & 2.0 \\
\hline 538 & " & " & Nagae-wase & 100 & 0 & 0 & 2.0 \\
\hline 546 & " & " & Ginbhozu & 100 & 0 & 0 & 2.0 \\
\hline 563 & " & " & Kinoshita-mochi & 100 & 0 & 0 & 2.0 \\
\hline 571 & " & " & Mansaku & 98 & 2 & 0 & 2.02 \\
\hline
\end{tabular}


Table 2. Variation in nucleolar number among strains of 0 . perennis and $O$. sativa f. spontanea

\begin{tabular}{|c|c|c|c|c|c|c|c|}
\hline \multirow{2}{*}{$\begin{array}{c}\text { Strain } \\
\text { No. }\end{array}$} & \multirow[t]{2}{*}{ Type* } & \multirow[t]{2}{*}{ Place of collection } & \multirow[t]{2}{*}{ Habitat } & \multicolumn{3}{|c|}{$\begin{array}{l}\text { No. of cells showing } \\
\text { each nucleolar No. }\end{array}$} & \multirow{2}{*}{$\begin{array}{l}\text { Mean No } \\
\text { per cell }\end{array}$} \\
\hline & & & & 2 & 3 & 4 & \\
\hline W102 & Spontanea & Patna, Cuttack, India & Marsh & 78 & 21 & 1 & 2.2 \\
\hline W106 & $" \prime$ & near Cuttack, India & $" \prime$ & 96 & 4 & 0 & 2.04 \\
\hline W107 & " & $" \prime$ & " & 52 & 29 & 19 & 2.8 \\
\hline W122 & $" \prime$ & $" \prime$ & $" \prime$ & 85 & 15 & 0 & 2.2 \\
\hline W153 & " & West Bengal, India & Deep paddy & 100 & 0 & 0 & 2.0 \\
\hline W140 & " & Trichur, Kerala, India & "I & 22 & 67 & 11 & 2.9 \\
\hline W141 & " & $"$ & $" 1$ & 94 & 6 & 0 & 2.1 \\
\hline W168 & " & Phimai, Thailand & Marsh & 74 & 24 & 2 & 2.3 \\
\hline W179 & $" \prime$ & Rojburi, Thailand & $" \prime$ & 87 & 13 & 0 & 2.1 \\
\hline W574 & $\prime \prime(?)$ & Malaya & & 77 & 23 & 0 & 2.2 \\
\hline W587 & " & $"$ & & 82 & 17 & 1 & 2.2 \\
\hline W593 & " & " & & 98 & 2 & 0 & 2.02 \\
\hline W594 & $" \prime$ & $"$ & & 95 & 3 & 2 & 2.1 \\
\hline W595 & $"$ (?) & $" \prime$ & & 95 & 4 & 1 & 2.1 \\
\hline W596 & $" \prime$ & $" \prime$ & & 94 & 3 & 3 & 2.1 \\
\hline W597 & " & " & & 78 & 19 & 3 & 2.3 \\
\hline W610 & " & Rangoon, Burma & & 21 & 64 & 15 & 3.0 \\
\hline W552 & " & Kuantong, China & & 27 & 61 & 12 & 2.8 \\
\hline W120 & Perennis & Cuttack, India & Pond & 57 & 36 & 7 & 2.5 \\
\hline W132 & $" \prime$ & Samalkot, India & Marsh & 43 & 51 & 6 & 2.6 \\
\hline W157 & $"$ & Assam, India & Pond & 70 & 22 & 8 & 2.4 \\
\hline W149 & $" \prime$ & Raipur, India & $" \prime$ & 35 & 64 & 1 & 2.7 \\
\hline W145 & " & Bangkok, Thailand & Marsh & 91 & 8 & 1 & 2.1 \\
\hline W146 & " & $" \prime$ & $" \prime$ & 17 & 65 & 18 & 3.0 \\
\hline W161 & " & Chiengmai, Thailand & " & 48 & 50 & 2 & 2.5 \\
\hline W164 & " & $" \prime$ & " & 45 & 47 & 8 & 2.6 \\
\hline W167 & $" \prime$ & Srisanrong, Thailand & $" \prime$ & 40 & 53 & 7 & 2.7 \\
\hline W175 & $" \prime$ & Nongkai, Thailand & Pond & 67 & 29 & 4 & 2.2 \\
\hline W178 & $" \prime$ & Ayuthya, Thailand & Deep paddy & 98 & 2 & 0 & 2.02 \\
\hline W031 & Barthii & Sudan, Africa & & 90 & 10 & 0 & 2.1 \\
\hline Af 61 & $"$ & Badeggi, Nigeria, Africa & Ditch & 35 & 61 & 4 & 2.7 \\
\hline Af 62 & " & $" \prime$ & $" \prime$ & 98 & 2 & 0 & 2.02 \\
\hline Af 67 & $"$ & Atebubu, Ghana, Africa & Pond & 40 & 44 & 16 & 2.8 \\
\hline W036 & Cubensis & Cuba, Central America & Marsh & 95 & 5 & 0 & 2.1 \\
\hline
\end{tabular}

*Classification into Perennis and Spontanea types was made according to Morishima, Oka and Chang (1961). Strains originally classified as "intermediate" type were included in Spontanea.

生種よりも 4 型が多いといえる。Morishima, Oka and Chang (1961) は O. perennis と O. sativa f. spontanea を種々の形質の変異に関して比較検討し, 両種の変異は連続的で両種を別の種として取扱らこと の妥当性は疑わしいと述べているが，これは仁数変異の結果からも興味のある問題である。さらに $O . g l a-$ berrima と O. breviligulata に共に 2 仁型が多いことは O. glaberrima が O. breviligulata と密接な 関係にあるという説と一致している。一方，W145 と W 146，W 140 と W 141 (Table 2) などはそれぞ れ両者方同一集団に属するともいえるほど近接した場所から採集されたものであるが，それらの間には仁数 
Table 3. Variation in nucleolar number among strains of O. glaberrima

\begin{tabular}{|c|c|c|c|c|c|}
\hline \multirow{2}{*}{$\begin{array}{l}\text { Strain } \\
\text { No. }\end{array}$} & \multirow{2}{*}{ Origin } & \multicolumn{3}{|c|}{$\begin{array}{l}\text { No. of cells showing } \\
\text { each nucleolar number }\end{array}$} & \multirow{2}{*}{$\begin{array}{l}\text { Mean No } \\
\text { per cell }\end{array}$} \\
\hline & & 2 & 3 & 4 & \\
\hline W411 & Guinea, Africa & 100 & 0 & 0 & 2.0 \\
\hline W416 & $" \prime$ & 63 & 31 & 6 & 2.4 \\
\hline W419 & " & 100 & 0 & 0 & 2.0 \\
\hline W436 & " & 99 & 1 & 0 & 2.01 \\
\hline W438 & $"$ & 100 & 0 & 0 & 2.0 \\
\hline W446 & " & 100 & 0 & 0 & 2.0 \\
\hline $\mathrm{W} 470$ & " & 100 & 0 & 0 & 2.0 \\
\hline W483 & $"$ & 99 & 1 & 0 & 2.01 \\
\hline W487 & " & 98 & 1 & 1 & 2.03 \\
\hline W493* & " & 72 & 26 & 2 & 2.3 \\
\hline W024 & From C. R. R. I., India & 100 & 0 & 0 & 2.0 \\
\hline W025 & " & 100 & 0 & 0 & 2.0 \\
\hline W026 & $" \prime$ & 100 & 0 & 0 & 2.0 \\
\hline W027 & " & 99 & 1 & 0 & 2.01 \\
\hline W028 & $"$ & 100 & 0 & 0 & 2.0 \\
\hline W037 & From Ag. Res. Ser., USDA & 100 & 0 & 0 & 2.0 \\
\hline W038 & $"$ & 100 & 0 & 0 & 2.0 \\
\hline W039 & $"$ & 99 & 1 & 0 & 2.01 \\
\hline W040 & $" \prime$ & 97 & 3 & 0 & 2.03 \\
\hline
\end{tabular}

*W493 was found to be O. sativa later.

Table 4. Variation in nucleolar number among strains of O. breviligulata (including $O$. staphii)

\begin{tabular}{|c|c|c|c|c|c|c|}
\hline \multirow{2}{*}{$\begin{array}{l}\text { Strain } \\
\text { No. }\end{array}$} & \multirow{2}{*}{ Place of collection } & \multirow{2}{*}{ Habitat } & \multicolumn{3}{|c|}{$\begin{array}{l}\text { No. of cells showing } \\
\text { each nucleolar number }\end{array}$} & \multirow{2}{*}{$\begin{array}{l}\text { Mean No. } \\
\text { per cell }\end{array}$} \\
\hline & & & 2 & 3 & 4 & \\
\hline Af 6 & Konakry, Guinea, Africa & Marsh & 100 & 0 & 0 & 2.0 \\
\hline Af 8 & Kobane, Guinea & " & 100 & 0 & 0 & 2.0 \\
\hline Af 13 & Niandamkolo, Guinea & Ditch & 99 & 1 & 0 & 2.01 \\
\hline Af 16 & Kogoni, Fr. Sudan & Marsh & 100 & 0 & 0 & 2.0 \\
\hline Af 19 & Segou, Fr. Sudan & Ditch & 100 & 0 & 0 & 2.0 \\
\hline Af 21 & $"$ & & 100 & 0 & 0 & 2.0 \\
\hline Af 24 & $"$ & & 98 & 1 & 1 & 2.03 \\
\hline Af 27 & " & & 92 & 7 & 1 & 2.1 \\
\hline Af 30 & " & & 71 & 24 & 5 & 2.3 \\
\hline Af 33 & $" \prime$ & & 99 & 1 & 0 & 2.01 \\
\hline Af 37 & " & & 98 & 1 & 1 & 2.03 \\
\hline Af 41 & $"$ & & 41 & 53 & 6 & 2.7 \\
\hline Af 42 & $" \prime$ & & 100 & 0 & 0 & 2.0 \\
\hline Af $66^{*}$ & Hohoe, Ghana & Rice field & 100 & 0 & 0 & 2.0 \\
\hline W009 & West Africa (From C.R.R.I., India) & & 97 & 1 & 2 & 2.05 \\
\hline W049 & Guinea, Africa & & 100 & 0 & 0 & 2.0 \\
\hline W607 & West Africa (From C.R.R.I., India) & & 98 & 2 & 0 & 2.02 \\
\hline W608 & $"$ & & 98 & 2 & 0 & 2.02 \\
\hline
\end{tabular}

*Af66 is a cultivated form, O. glaberrima. 
Table 5. Distributions of mean nucleolar number per cell in different Oryza species

\begin{tabular}{|c|c|c|c|c|c|c|c|c|c|c|c|c|c|}
\hline \multirow{2}{*}{ Species and types } & \multicolumn{12}{|c|}{ Mean number of nucleoli per cell } & \multirow{2}{*}{$\begin{array}{l}\text { No. of } \\
\text { strains }\end{array}$} \\
\hline & 2.0 & $2.01 \sim 2.04$ & 2.1 & 2.2 & 2.3 & 2.4 & 2.5 & 2.6 & 2.7 & 2.8 & 2.9 & 3.0 & \\
\hline \multicolumn{14}{|l|}{ O. sativa } \\
\hline Indica (Continental) & 2 & 1 & 3 & 2 & 1 & 2 & & & & & & & 11 \\
\hline Japonica (Insular) & 4 & 4 & & 1 & & & & & & & & & 9 \\
\hline \multirow{2}{*}{\multicolumn{14}{|c|}{$\begin{array}{l}\text { O. perennis and } \\
\text { O. sativa f. spontanea }\end{array}$}} \\
\hline & & & & & & & & & & & & & \\
\hline Spontanea & 1 & 2 & 5 & 4 & 2 & & & & & 2 & 1 & 1 & 18 \\
\hline Perennis & & 1 & 1 & 1 & & 1 & 2 & 2 & 2 & & & 1 & 11 \\
\hline Barthii & & 1 & 1 & & & & & & 1 & 1 & & & 4 \\
\hline Cubensis & & & 1 & & & & & & & & & & 1 \\
\hline O. glaberrima & 11 & 6 & & & & 1 & & & & & & & 18 \\
\hline O. breviligulata & 8 & 6 & 2 & & 1 & & & & 1 & & & & 18 \\
\hline
\end{tabular}

についていちじるしい差が見出される。このことは同一集団内でも個体により仁形成力が異なることを暗示 している。

\section{要 約}

1. O. sativa, O. perennis, O. sativa f. spontanea, O. glaberrima, O. breviligulata の各種につ いて，それぞれ約 20 系統の体細胞分裂終期に䋆ける数变異を観察した。

2. 観察の結果は, 化数変異は連続的であり，いわゆる 2 型㸩よび 4 型が全部の種にわたって存在す ることを示した。O. sativa の内 Japonica 型は 2 型の代表的のものであるが, Perennis 型拉よび

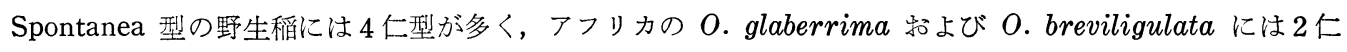
型が多いことがわかった。

謝 辞

この研究は 1960 年 8 月から 1961 年 3 月まで国立遺伝学研究所で扢こなったものである。研究にあたっ て終始御指導を賜った竹中要博土，岡彦一博士並びに稲研究委員会の方々に謹んで感謝の意を表する。

な特, 本研究はロックフェラー財団の補助による「栽培稲の起源に関する研究」の一環として行なわれた るのである。

\section{引用 文 献}

Morishima, H., H. I. Oka and W. T. Chang 1961 Directions of differentiation in populations of wild rice, Oryza perennis and O. sativa f. spontanea. Evolution 15: 350-363.

Oka, H. I. and C. Kao 1956 Variation in nucleolar number among varieties of cultivated rice. Cytologia 21: 44-49.

酒井寛一 1938. 稲の仁と仁染色体。明峰教授記念農学論叢：161-168. 養賢堂. 東京.

Selim, A. G. 1930 A cytological study of Oryza sativa L. Cytologia 2: 1-26. 